\title{
FACTORS AFFECTING THE NUMBER OF VISITS OF ZOOS IN THE CZECH REPUBLIC
}

\author{
Markéta Kalábová ${ }^{1}$ \\ Lukáš Nekolný ${ }^{2}$ (i) \\ Linda Machová ${ }^{3}$ \\ Zdenka Petrů ${ }^{4}$
}

DOI: https://doi.org/10.31410/tmt.2019.603

\begin{abstract}
Zoological gardens represent a very important part of tourism. The main aim of this contribution is to find out which factors have significant impact on number of visits in zoos in the Czech Republic. The scripting language $R$ was used for statistical evaluation. After statistical evaluation using the Spearman correlation coefficient, it was found that the factors related to the number of zoo visits are the level of own income adjusted for admission, which was evaluated for a very strong correlation rate, i.e. Spearman correlation coefficient 0.92 and p-value (after Holm correction) $7 \cdot 10^{-9}$, and the amount of adult admission with a slightly lower correlation rate, i.e. 0.69 and p-value 0.03. Other analysed factors, i.e. the size of the exposition part of the zoo (Spearman 0.58, p-value 0.11), the total number of species kept in the zoo (Spearman 0.44, p-value 0.31), the amount of public subsidies provided to the zoo (Spearman 0.54, p-value 0.16), the number of inhabitants in the region (Spearman-0.19, p-value 0.8) and the number of tourists in the region (Spearman 0.23, p-value 0.8) in which the zoo is located have no significant impact on attendance.
\end{abstract}

Keywords: zoological gardens, attendance, wildlife tourism, tourism, Czech Republic.

\section{INTRODUCTION}

$\mathrm{H}$ gginbottom (2004) claims that the increasing interest of contemporary society is devoted to living nature and animals. Their role is mentioned, for example, by Carr (2009). Wildlife tourism is one of the types of tourism according to its focus and motivation. According to Higginbottom (2004), it is divided into wildlife-watching tourism, hunting tourism, fishing tourism and, last but not least, captive-wildlife tourism, i.e. tourism directed to a captive animal breeding facility, of which so-called zoo tourism is a key component. As Turley (2001) and Frost (2011) mention, for a long time nobody has been looking at the zoo as a tourist and leisure attraction. The first studies were not made until the 1970s in the United States (Turley 2001). Mason (1999) even pointed out that most texts on tourist destinations and tourism, including cities, emphasize the zoo only marginally. In the last three decades, however, many extensive works began to be produced, such as Shackley (1996), Higginbottom (2004) or Frost (2011).

The animal management system is very diverse in the world. Given the need to address this issue worldwide, there are international organizations involved in animal husbandry. A very important area is primarily the way of game management by hunting. Hunting is considered an instrument of animal protection (European Federation for Hunting and Conservation, 2004). The aim is to keep

University of Economics, Prague, W. Churchill Sq. 1938/4, 13067 Prague 3, Czech Republic

Charles University, Albertov 6, 12843 Prague 2, Czech Republic

University of Economics, Prague, W. Churchill Sq. 1938/4, 13067 Prague 3, Czech Republic

University of Economics, Prague, W. Churchill Sq. 1938/4, 13067 Prague 3, Czech Republic 
animal populations in sustainable numbers. Hunting, especially by foreign hunters, is an important source of income for rural development for many countries, especially in the transformation process, but also a direct source of funding for rescue programs - strengthening animal protection legislative documents, monitoring wildlife, promoting science in this area, financial resources for damages and projects enhancing the education of the local population in relation to wildlife (Kalábová, 2019).

Artificial conservation of populations in zoos is another possibility of game protection. Zoological gardens have very important functions. Besides conservation and protection of animals they support education of people visiting zoos and they also represent economic source for the locality (Hosey, Melfi, Pankhurst, 2013). Zoos are economically active, they buy goods and services, they can bring foreign exchange earnings to the country, generate job opportunities. Local economies often benefit from zoos more than expected, as the Toledo Zoo study showed. During the four years of its existence, its economic benefits amounted to approximately $\$ 350$ million (Toledo Business Journal, 2004). An extraordinary benefit of running a zoo was also found in the results of the Detroit Zoo study, which reported a total benefit (including both direct and indirect and induced effects) for 2013 when the local economy worth more than $\$ 100$ million (Detroit Zoo, 2014) Australia's zoos reached an annual turnover of \$ 143 million at the turn of the 20th and 21st centuries (Higginbottom, 2004).

In order to analyse and subsequently increase or revitalize the attendance of zoos, it is necessary to determine the factors that influence their number of visits. It is crucial to emphasize that many people go to the zoo repeatedly, so it should be used the term number of visits instead of more often number of visitors (Smith, 2013). It is appropriate to take into account especially those factors that can be influenced either by the zoo itself or by another subject. For this reason, factors such as weather (temperature, total precipitation) or visit period (season, day of the week, school holidays, etc.) will not be included. These factors cannot be influenced and their impact can be expected without research. The main aim of this contribution is to find out which factors have significant impact on number of visits in zoos in the Czech Republic.

\section{LITERATURE REVIEW}

Tourist attractions built a key role in system of tourist offer. They can be very different from many points of view (Kušen 2010). The term Zoo tourism - a part of wildlife tourism - was highlighted by Mason (2000). Wildlife tourism is characterized as a tourism based on encounters with wild (non-domesticated) animals. They can be occurred in natural environment or in captivity (Higginbottom, 2004). Another author (Newsome, 2005) distinguishes non-consumptive tourism (wildlife watching, photography and feeding) and consumptive tourism (hunting and fishing).

A lot of definitions of zoos exist. According to Habel and Mroczkowski (2015) zoo is a place where animals are kept, exhibited and bred. Hosey, Melfi and Pankhurst (2013) consider a zoo as a place where only exotic animals are kept. This could lead to a broad discussion which animals are exotic and which not. Zoos are social constructs like museums (Hoage, Deiss, 1996). There is also a big variety of different types of zoos as well as range of their names: e.g. zoological garden, safari park, wildlife park, farm park, aquarium, bird park (Nekolný, Fialová, 2018b).

The attendance is one of the basic quantitative scales of success as well as failure of tourist destinations and attractions. The attendance data play a crucial role in destination management and in economic factors such as different structure of visitors, too. Zoos traditionally belong to 
the most visited (not only paid) tourist and leisure attractions (Baratay, Hardouin-Fugier 2004). Authors who focus on factors influencing attendance of zoos are not so many - methodically e.g. Nekolný, Fialová (2018a) who refer to different approaches of annual passes counting. Whitworth and Clifton (2012) analyse factors that determine the zoo attendance of zoos, as a case study of the United Kingdom. For this purpose, there were selected 55 British zoos - members of the British and Irish Association of Zoos and Aquariums (BIAZA). In the end only 34 of them were used for research, as the remaining zoos did not have all the necessary data to carry it out. In addition to factors affecting the attendance of British zoos, the authors monitor geographical distribution of zoos and suggest a way to determine the zoo's popularity index based on the species. Studies with similar themes are written by Moriss (1959) and Davey (2007).

\subsection{Zoos in the Czech Republic}

The Union of Czech and Slovak Zoos (UCSZOO) is an association of zoos and citizens who contribute or have contributed to the development of zoos in an extraordinary way. Almost forty thousand individual animals were kept in the twenty member zoos of this organization in the Czech Republic and Slovakia in 2017 (UCSZOO, 2018).

Over six million visits came to Czech UCSZOO members in 2016, and it was an increase of almost half a million compared to 2015. Most visits were registered in the Prague Zoo, which was visited by almost 1.5 million people. About half the number of visits was recorded in the Zlín Zoo, which is still the second highest number of visits in that year. The third most visited zoo in the Czech Republic in 2016 was the zoo in Dvůr Králové with more than 530,000 visitors. The least visited zoo in 2016 was the Děčín Zoo with approximately 115,000 visitors (UCSZOO, 2017).

In 2018, eleven zoos in the Czech Republic were regular members of the World Association of Zoos and Aquariums (WAZA), accounting for about $4 \%$ of all member zoos and aquariums. Fourteen Czech zoos were registered in the European Association of Zoos and Aquariums in the same year. Only two zoos in the Czech Republic, which are members of the UCSZOO, are not also members of this European organization, namely Vyškov Zoo and Chleby Zoo (UCSZOO, 2018; WAZA, 2019;).

There are approximately fourteen zoos in the Czech Republic per $100,000 \mathrm{~km}^{2}$, the fifth rank in the world according to members of WAZA. Despite the fact that there are absolutely the most zoos or aquariums in territory of USA, the United States of America placed in the imaginary ranking in the second half, with less than one member per 100,000 $\mathrm{km}^{2}$ (WAZA, 2019).

If the number of members in WAZA is recalculated on the basis of population, i.e. the number of zoos or aquariums per 1 million inhabitants, there would be almost exactly one zoo in the Czech Republic, which is the highest value. Other ranks would be placed by Denmark and Estonia (WAZA, 2019).

\section{METHODOLOGY}

There were 15 zoos included and compared: Zoos in Brno, Děčín, Dvưr Králové, Hluboká, Hodonín, Chomutov, Jihlava, Liberec, Olomouc, Ostrava, Plzeň, Praha, Ústí nad Labem, Vyškov, Zlín.

The scripting language $\mathrm{R}$ was used for statistical evaluation. $\mathrm{R}$ represents a language suitable for statistical calculations and graphical representations. RStudio was used to facilitate the work. 
Hypotheses were tested using a linear model (regression), i.e. R function of $1 \mathrm{~m}$. The attendant variable will be the number of visitors to the zoo; all other variables, resp. factors, i.e. the size of the zoo, own income without admission, the number of species of kept animals, the number of tourists in the region and the number of inhabitants, the price of adult admission in summer and public subsidies. The model was then simplified by backward selection, which gradually eliminates those independent variables that do not have a significant effect on the dependent variable. The significance level against which the $\mathrm{p}$-values of the individual factors will be compared, was determined at the normal 0.05 .

Considering the existence of outliers in the original model (in the next model after their elimination, the residuals did not have a normal distribution, therefore the regression assumptions were not met), the Spearman correlation coefficient with the Holm correction was used.

The following hypotheses were chosen to be proved:

\section{Hypotheses 1: The size of the exposition part affects the number of visits.}

According to the hypothesis, the larger area of the exposition part should increase the attractiveness and thus the attendance of the zoo, i.e. the larger the exposition part, the more visitors the given zoo will attract. The larger area of the exposition part means larger runs for animals or a larger number of runs that can attract more visitors than the small zoo.

\section{Hypotheses 2: The number of animal species affects the number of visits}

The more species of animals a visitor can see, the more attractive the zoo should be.

Hypotheses 3: The number of tourists in a given region is related to the number of visits to the zoo in that region.

As visiting a zoo may be one of the tourists' destinations in that region. Therefore, the more tourists the region has, the higher the number of visitors the zoo should show.

\section{Hypotheses 4: Own income without admission has an impact on the number of visits.}

Higher income without admission should allow the zoo to use higher money for advertising and marketing in general, as well as to improve the visitor infrastructure. Revenue will be adjusted for admission revenue as the amount to be collected depends on the number of visits.

\section{Hypotheses 5: Public subsidies do not affect the number of visits}

Subsidies from public budgets are unlikely to be granted for marketing purposes to attract more visitors, but rather to zoo activities aimed at protecting nature and protected species, etc.

\section{Hypotheses 6: The amount of admission is related to the number of visits to the zoo}

It can be assumed that the zoo will choose a level of admission that corresponds to its popularity and willingness of potential visitors to pay it. The hypothesis is based on the assumption that a popular zoo can afford to sell a higher admission fee (visitors have no problem to pay it, consider 
it proportional to the quality of the experience of visiting the zoo) and vice versa less popular zoo collects a lower admission.

Hypotheses 7: The number of inhabitants of the region affects the number of visits to the zoo in the region

Visiting a zoo is often a one-day activity, so it can be assumed that a visitor will often prefer a zoo located in the vicinity of his/her home, which he/she will not have to commute far to.

Mainly statistical data from the annual report of the UCSZOO for 2016 will be used, because at the time of processing the statistical evaluation was not yet available new version of data statistics.

In accordance with the hypotheses, the following factors will be selected from the 2016 annual report for all 15 Czech members of UCSZOO: attendance of zoos at hundreds of thousands, area of the zoo (exposition part) in hectares, own income without admission in hundreds of thousands of crowns, number of species of kept game in units, price of adult admission in summer in crowns and public subsidies in hundreds of thousands of crowns. Another factor, the number of tourists (stated in the statistics as "guests") in the region in hundreds of thousands, was taken from the Public Database of the Czech Statistical Office for 2016. Guests here mean persons who stayed overnight in collective accommodation facilities, including children. The factor of population in given regions in hundreds of thousands is also from the data of the Czech Statistical Office. The data were collected from January to April 2019.

\section{RESULTS OF STUDY AND DISCUSSION}

The number of zoo visits is influenced by own income adjusted for admission and adult admission in the summer, based on the evaluation of data using the Spearman correlation coefficient with the Holm correction (presented in Table 1).

Table 1: Results of statistical evaluation

\begin{tabular}{|l|c|c|c|c|}
\hline Factor & rho & S & p-value & $\begin{array}{c}\text { p-value after } \\
\text { correction }\end{array}$ \\
\hline $\begin{array}{l}\text { Number of } \\
\text { inhabitants }\end{array}$ & $-0,190652416$ & 666,7654 & 0,496112047 & 0,803237583 \\
\hline Number of tourists & 0,233819001 & 429,0614 & 0,401618792 & 0,803237583 \\
\hline $\begin{array}{l}\text { Own income } \\
\text { without admission }\end{array}$ & 0,917857143 & 46 & $1,00 \mathrm{E}-09$ & $7,00 \mathrm{E}-09$ \\
\hline Admission & 0,693092049 & 171,8685 & 0,004172099 & 0,025032593 \\
\hline Number of species & 0,439285714 & 314 & 0,103199216 & 0,309597648 \\
\hline Exposition area & 0,584974102 & 232,4145 & 0,021984425 & 0,109922126 \\
\hline Public subsidies & 0,542857143 & 256 & 0,039158555 & 0,156634221 \\
\hline
\end{tabular}

Source: authors research

Own income without admission is the most significant variable with p-value after the Holm correction $7-10^{-9}$. The correlation coefficient of this variable is 0.918 , which indicates a very strong positive correlation. As for the adult admission rate in the summer, the $\mathrm{p}$-value after the Holm correction is 0.025 and the correlation coefficient is 0.693 , which in this case also indicates a relatively strong positive correlation, albeit less than for own income without admission. 
The results of the statistical survey showed that own incomes without admission and the amount of admission for adults are important. All other tested factors were evaluated as insignificant, i.e. the number of kept animal species, the size of the exposition part of the zoo, the population of the region where the zoo is located, the number of tourists in the given region and public subsidies. The observed relation of zoo attendance with own income adjusted for admission and for adult admission is in line with hypotheses, as well as evaluation of public subsidies as insignificant.

\subsection{Factors affecting the zoo attendance}

Regarding the factors affecting the attendance of the zoo, the results of the statistical evaluation were consistent with hypothesis no. 4 and no. 6 .

\section{Own income without admission}

The lowest $p$-value and very strong positive correlation were evaluated for the own income factor without admission. The higher own incomes without admission a zoo has, the more visitors visit a zoo and vice versa, which is in line with the hypothesis. The six least visited zoos are also zoos, which have the lowest of all their own income net of admission, i.e. Děčín Zoo (2.1 million CZK), Hodonín Zoo (2.3 million CZK), Hluboká Zoo (2.8 million CZK), Vyškov Zoo (3.5 million CZK) and Ústí Zoo (6.8 million CZK). Moreover, the zoos with the highest own income without admission, i.e. Prague Zoo (115.6 million CZK), Dvůr Králové Zoo (64 million CZK) and Zlín Zoo (29 million CZK) represent the three most visited zoos in the Czech Republic, too.

Zoos that thrive financially, respectively, have enough of their own earnings, they can be more attractive to potential visitors. Such zoos have more funding for modernization and reconstruction of the complexes, construction of new pavilions, accompanying events and advertising etc. With these activities, zoos have a greater potential to attract more visitors.

According to the Whitworth study (2012), zoos that do not suffer from financial distress and have enough income have better prerequisites to provide a high standard of living for animals, sufficient educational opportunities for visitors, and to develop their activities and conservation efforts. These areas are among the fundamental aspects that justify the existence of zoos and similar institutions.

\section{Admission for adults}

According to the results, hypothesis no. 6 was not refuted. The amount of admission is related to the number of visits. In some zoos, dependence is evident through observation with increasing admission, attendance increases and vice versa (e.g. Prague Zoo highest admission and most visitors, Dvůr Králové Zoo - second highest admission and third most visited zoo, Liberec Zoo fifth highest admission and the sixth most visited zoo).

It can be assumed that a potential visitor is not surprised to pay a higher admission fee at Prague Zoo than in any other zoo in the Czech Republic, and if the admission price at the Prague zoo does not exceed the acceptable limit, it is highly likely that people will continue to visit it (image, prestige, diverse animal species or pleasant visitor infrastructure, etc.), although it collects the highest admission fees from visitors. However, for other zoos that are not so notorious, it is 
possible that any significant increase in admission could discourage potential visitors, since its amount would not be considered to be proportional to the quality of the zoo experience.

In some zoos, this correlation is less obvious. For example, it is a zoo in Ústí nad Labem, whose admission is the sixth highest, but in terms of attendance, the second least (fourteenth) visited. Chomutov Zoo collects the lowest admission overall, but in attendance is the tenth most visited one. To other examples belong Děčín Zoo (the fourth lowest admission, but the least visited zoo) or Ostrava Zoo (the seventh highest admission, but the fourth most visited zoo). However, no significant deviations were observed.

In the aforementioned Whitworth study (2012), the connection between the amount of admission and the number of visits was pointed out. Specifically, it was a positive correlation between these variables. At the same time, it was shown that dependence is also reported between the input and the popularity index of the zoo (calculated according to the popularity index of the animals kept). It applies here that the more popular zoo is, the higher admission zoo can afford. It must be assumed that the amount of admission is not only influenced by the image and popularity of the zoo, but also by the standard of living of the inhabitants of the area, their salary conditions, the location of the zoo, etc.

\subsection{Factors not affecting attendance in zoos}

According to the results of the statistical evaluation, the following factors do not affect the attendance: number of kept species, number of inhabitants of the region in which the zoo is located, number of tourists in the region, area of the exposition part of the zoo and public subsidies. Concerning the set hypotheses, hypothesis 5 , which states that public subsidies do not affect the number of visitors to the zoo, has not been refuted.

\section{Number of kept species}

Although it may seem that some zoos have a relationship between attendance and the number of species kept by the zoo (Vyškov Zoo with 116 species and Děčín Zoo with 164 species are among the seven least visited zoos, in contrast, Ostrava Zoo with 437 species, i.e. with the third highest number of kept species, it is the fourth most visited zoo in the Czech Republic) and therefore the hypothesis could be confirmed, the results do not support this hypothesis.

Zoo attendance is influenced, rather than by the quantity of animal species, by specific species of animals or by certain characteristics that seem attractive to visitors. Many authors talk about "flag animals", "iconic animals", "money makers", "stars", or charismatic megafauna (e.g. Howell, McLeod, \& Coleman, 2019; Sheridan, 2016; Skibins et al., 2017). Mooney et al. (2020) say that it is just charismatic megafauna, which can influence positively the attendance. Sheridan (2016) emphasizes not only big elephants or giraffes, but smaller meerkats are magnets for visitors. Also, according to Morris's study (1961) various monkeys, chimpanzees, horses, combos (semi-monkeys), giant pandas, bears, lions, elephants or tigers are considered as popular animals.

On the other hand, not very attractive animals are mainly species such as snakes, spiders, skunks, rats and crocodiles, but also the aforementioned lions, which are therefore considered both attractive and unpopular. Equally surprising is that, according to Morris (1961) gorillas, hippos, tigers and rhinos are also considered to be less attractive. 
Based on Whitworth's study (2012), visitors prefer animals that possess properties that are considered interesting and attractive. Popular are therefore animals that are lively and active, well visible, intelligent, varied, have the ability to hold things, densely coated, rare, fast, exotic, can move quickly, have large eyes or climb or swim, etc. The smelly animals are slimy, poisonous, hairless and aggressive towards each other, bite, have no or have more than four legs or are dangerous to humans, are less popular and are unlikely to attract visitors to the zoo. According to Whitworth's study (2012) the most popular of the mammals are apes, and surprisingly squirrels, zebras, elephants and giraffes. On the other hand, hippos, insectivores or aardvarks do not enjoy the same group. Among the birds are especially parrots and songbirds, unpopular felines. Among the snakes and amphibians are the most popular iguanas and frogs; on the opposite side of the species popularity chart are crocodiles and alligators.

Whitworth's study (2012) also refuted the earlier assumption that visitors prefer large animals to smaller animals. On the contrary, smaller animals were rated as more popular. According to the evaluation of the properties that visitors appreciate on the animals, their visibility is particularly important, i.e. if the animal is clearly visible to the visitors, its growth does not play a role in evaluating the popularity.

In general, mammals are the most attractive species for visitors (Moss, Esson, 2010; Carr, 2016). Therefore, it should be analysed if there is any correlation between the attendance and the number of mammal species. On the other side, there could be a huge problem in a number or percentage of kept species, which are also exhibited. There is a lot of small or rare species with the necessity of calm non-public breeding facility.

\section{Area of the exposition part of the zoo}

According to the study, the size of the exposition part of the zoo as an independent factor has no influence on attendance, which can be seen especially in the Chomutov Zoo (112 ha), whose area is the largest of all member zoos. Prague Zoo (50 ha) can attract five times more visits with approximately half the area. Liberec Zoo, the sixth most visited zoo, is the area of the tenth largest zoo. On the other hand, the larger zoo can have the higher capacity of its area.

\section{Population of the region}

The number of inhabitants in the region does not affect the number of visits to the zoo, which is located in the region, so hypothesis no. 7 is refuted. A visit to the zoo is considered to be a frequent one-day activity and it could be assumed that in most cases the visitor will not spend a lot of time travelling to the zoo and will travel mainly to zoos that are relatively close to their residence. The independence of visitors to the region's population may be evident, for example, at Prague Zoo or Dvůr Králové Zoo, which are one of the three most visited zoos. These zoos are most probably visited by a lot of visitors from other regions or even countries.

Another possible reason for the rebuttal of the hypothesis may be the residents in relative proximity to the border of the region, for which it is not time consuming to visit a zoo that would be located in another region. Davey's study (2007) reports a correlation between the number of zoo visits and populations, but internationally. According to this study, the highest attendance of zoos has been registered in Japan for a long time. On the other hand, New Zealand has the least number of visits to this attraction, just before Great Britain (Whitworth, 2012). The Whitworth study then 
monitors the impact of population at regional level, namely three distances from zoos (around $24 \mathrm{~km}, 63 \mathrm{~km}$ and $121 \mathrm{~km}$ ), whose populations were tested. However, even on the basis of these results, the effect of this factor at regional level has not been demonstrated. As well as the populations of the areas in question, no other demographic factors have been assessed as significant.

It should be noted, however, that the effect of this factor in the study may be influenced by the fact that fourteen regions of the Czech Republic appeared in the model only nine of them, so it is clear that in some cases there are more zoos in one region (Brno Zoo, Hodonín Zoo and Vyškov Zoo are all located in the South Moravian Region).

\section{Tourists in the region}

The number of tourists in a given region has no influence on the attendance of zoos and hypothesis no. 3 has been refuted. Given that in many countries (probably also in the Czech Republic) a visit to the zoo is usually considered a one-day activity often performed by residents of the area, therefore, the influence of this factor is limited and thus this factor may not have the meaning as assumed in the hypotheses.

However, this factor can be influenced by occasional duplication and triplicity of regions as well as population. In this case, the effect of this factor is even more debatable, as it can be assumed that tourists who go on holiday to the region choose only one of the zoos located in the region and spend the rest of their vacation visiting other attractions (unless they are tourists looking especially for zoos). In the previous case (factor of population in the given region) it is possible to conclude that the inhabitants of the region visit several zoos in their region because they live in it. They do not have significantly limited time (e.g. a few days) to visit the attractions of the region as holidaymakers, and visiting the zoo is a popular one-day activity often performed by residents of the area.

\section{Public subsidies}

According to the results, the number of public subsidies is not relevant in relation to attendance, which is in line with hypothesis 5. Act No. 162/2003 Coll., On the Conditions of Operation of Zoos and on the Amendment of Certain Acts lists cases where a zoo is entitled to financial support from public sources. From state or other public budgets, holders of licenses for the operation of zoos are provided with subsidies mainly for breeding and care of protected animals, keeping their herd books, projects focused on nature conservation, science and research or education, education and other cultural activities, construction, respectively reconstruction of the zoo and its buildings, further education of employees of the zoo or security and fire protection systems.

It is therefore clear that subsidies are not provided for marketing or such purposes, which should more likely attract potential visitors to visit the zoo. It is necessary to use own income for these activities. The reconstruction of the zoo and cultural activities is questionable.

\section{LIMITATION OF THE STUDY}

The elimination of three zoos as outliers, which was one fifth of the whole set, reduced the already small set. In this case, however, it was not possible to enlarge the sample in any way, because the data on zoos necessary to conduct the study were available only for the UCSZOO 
member zoos. However, in the new outlier-free model, the residuals did not have a normal distribution by Q-Q fence and, therefore, regression was not suitable for statistical evaluation (Graph 1). Although it was apparent from the graph (Q-Q plot) that the method was not suitable, the results were also evaluated for this test (Graph 2).

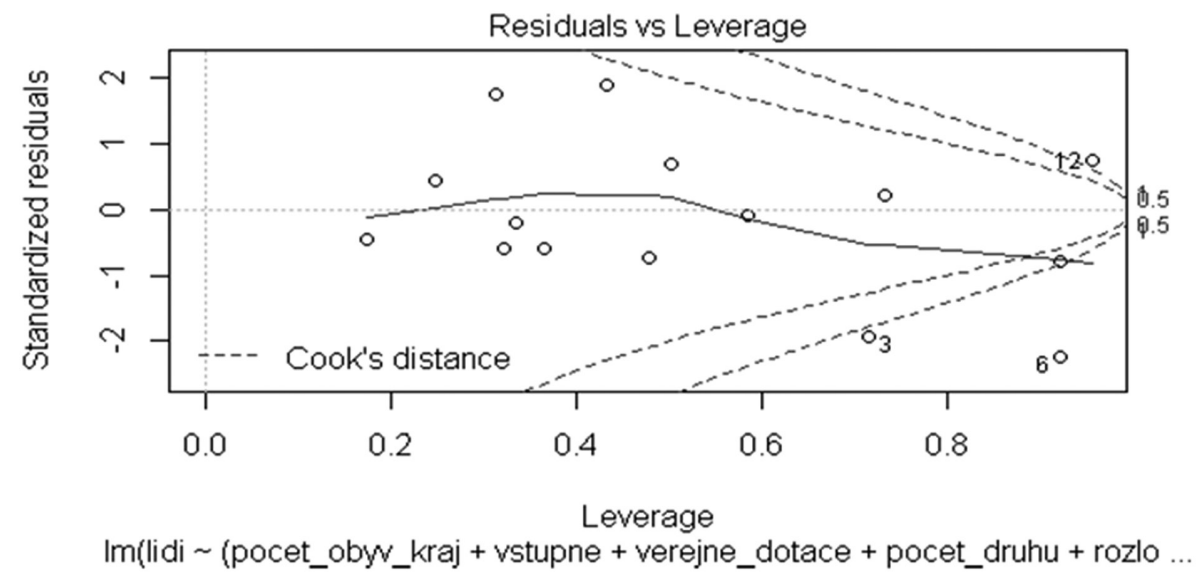

Graph 1: Prague Zoo, Dvůr Králové Zoo and Chomutov Zoo as outlier

Source: authors research

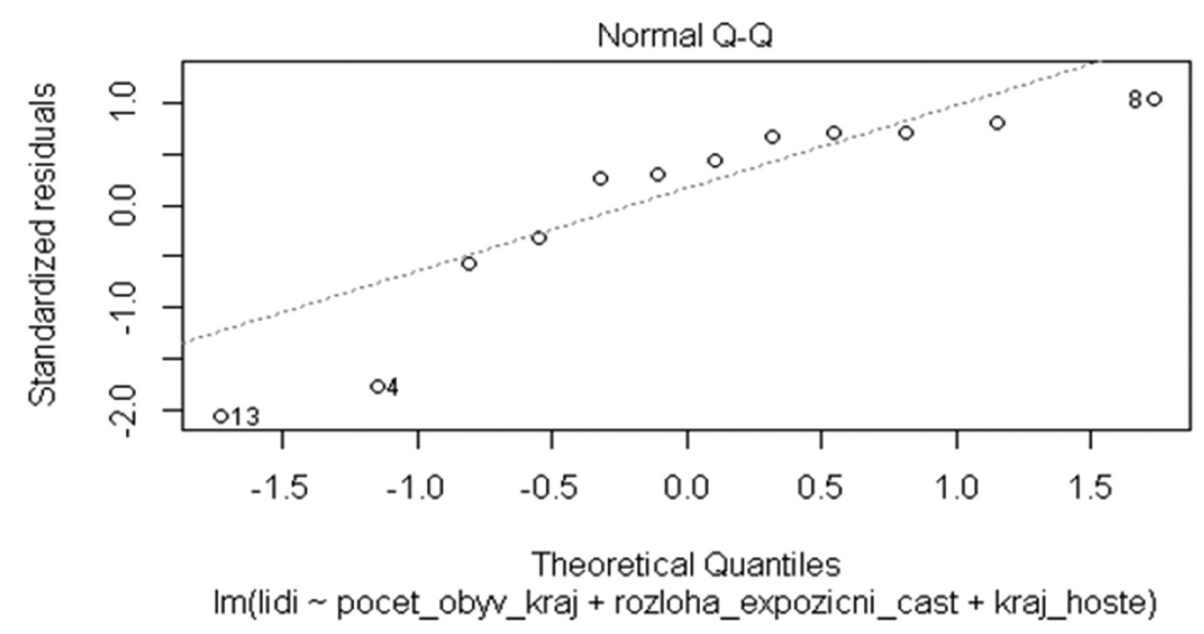

Graph 2: Q-Q plot

Source: authors research

\section{CONCLUSION}

The main aim of this contribution was to find out which factors influence the attendance of zoos in the Czech Republic. After statistical evaluation using the Spearman correlation coefficient with the Holm correction, it was found that the factors related to the number of zoo visits are the level of own income adjusted for admission, which was evaluated for a very strong correlation rate, i.e. Spearman correlation coefficient 0.92 and p-value (after Holm correction) $7 \cdot 10^{-9}$, and the amount of adult admission with a slightly lower correlation rate, i.e. 0.69 and p-value 0.03 . Other factors, i.e. the size of the exposition part of the zoo (Spearman 0.58, p-value 0.11), the number of species kept in the zoo (Spearman 0.44, p-value 0.31), the amount of public subsidies provided to the zoo (Spearman 0.54, p-value 0.16), the number of inhabitants in the region (Spearman $-0.19, \mathrm{p}$-value 0.8 ) and the number of tourists in the region (Spearman 0.23, p-value 0.8) in which the zoo is located have no significant impact on attendance. 
Therefore, a large influence of financial variables has been proved (except for public subsidies provided for specific purposes, which are precisely defined by Act No. 162/2003 Coll., On the Conditions of Operation of Zoos and on the Amendment of Certain Acts). From a financial point of view, prosperous zoos are better placed to attract visitors, whether through marketing activities or improving the visitor infrastructure, etc. The amount of admission is probably related to the popularity of the zoo and its general ability to convince a potential visitor that the amount of admission is proportional to the quality of the zoo experience and hence the money is worth spending.

As for the secondary objective, i.e. to assess the popularity of zoos in the Czech Republic compared to abroad, the Czech Republic stands out clearly over other countries whose zoos are members of the World Association of Zoos and Aquariums. If the area of the state were taken as the criterion for the conversion of the frequency of zoos, the fifth highest number of zoos would be in the Czech Republic. In the case of conversion according to the second criterion, i.e. according to the population of the given state, the Czech Republic would have even the highest number of zoos.

The potential of tourism behind zoos, i.e. zoo tourism, is undisputed in the Czech Republic, which also resulted from a comparison of the frequency of zoos with foreign countries, where the Czech Republic would prevail over states such as Germany or the United States of America. Among the twenty most visited places in the Czech Republic in 2016, zoos represented six times the number, so zoos represented $30 \%$ of all tourist attractions.

Zoos are not only important in terms of tourism; they are also expected to provide a casual form of biodiversity education, which is not so common with the most popular tourist destinations. Most of the frequently visited places are cultural attractions that are also important in terms of education, unlike zoos, but especially in the field of history or culture. Essential part of the most visited places are also attractions of an entertaining character, where the educational function is not very expected. Combination of nature conservation, education about biodiversity together with recreation and entertainment in zoos is therefore unique. Many zoos also strive to protect biodiversity. They are also important for both local and national economies. For these reasons, zoo tourism should not be neglected and its prosperity should be systematically pursued.

\section{REFERENCES}

Baratay, E., Hardouin-Fugier, E. [translated by Oliver Welsh] (2004). ZOO: a history of zoological gardens in the West. Pbk. ed. London: Reaktion books.

Carr, N. (2009). Animals in the tourism and leisure experience. Current Issues in Tourism, 12(5-6), 409-411.

Carr, N. (2016). An analysis of zoo visitors' favourite and least favourite animals. Tourism Management Perspectives, 20(1), 70-76.

Czech Statistical Office [ČSÚ] (2016). Návštěvnost HUZ podle kategorie-územní srovnáni - obdobi: 2016. Retrieved February 4, 2019 from: https://vdb.czso. $\mathrm{cz} / \mathrm{vdbvo} 2 / \mathrm{faces} / \mathrm{cs} /$ index.jsf? page $=$ vystup-objekt\&z $=\mathrm{T} \& \mathrm{f}=\mathrm{TABULKA} \& \mathrm{kata}-$ $\log =31743 \& \mathrm{pvo}=\mathrm{CRUD} 002 \& \mathrm{c}=\mathrm{v} 3 \sim 8 \_$RP2016\&v $=\mathrm{v} 90 \_$KAT__154__

Czech Statistical Office [ČSÚ] (2016). Počet obyvatel v regionech soudržnosti, krajich a okresech České republiky - obdobi: 2016. Retrieved February 4, 2019 from: https://www. czso.cz/documents/10180/32853387/1300721601.xlsx/42a23540-2943-4269-a537-34a11ff3e379? version $=1.0$ 
Davey, G. (2007). An analysis of country, socio-economic and time factors on worldwide zoo attendance during a 40 year period. International Zoo Yearbook, 41, 217-225.

Detroit Zoo boosts local economy with impact of \$100 million (2014). Michigan Chronicle, 77(29), 1 - A.5.

European Federation for Hunting and Conservation. (2004). Hunting abroad - position paper of FACE. Retrieved March 03, 2019 from: www.face.eu/sites/default/files/documents/english/position_paper_hunttour_-_en.pdf

Frost, W. (2011). Zoos and Tourism: Conservation, Education, Entertainment?. Buffalo: Channel View Publications, Aspects of tourism.

Habel, A., Mroczkowski, S. (2015). Cele i zadania ogrodow zoologicznych (The objectives and tasks of zoos). Journal of Education, Health and Sport, 5(8), 521-528.

Higginbottom, K. (2004). Wildlife tourism: impacts, management and planning. Retrieved January 31, 2019 from: http://sustain.pata.org/wp-content/uploads/2014/12/WildlifeTourism-impacts.pdf

Hoage, R. J., Deiss, W. A. (1996). New worlds, new animals: from menagerie to zoological park in the nineteenth century. Baltimore: Johns Hopkins University Press.

Hosey, G., Melfi, V., Pankhurst, S. (2013). Zoo Animals: Behaviour, Management, and Welfare. Oxford: OUP Oxford.

Howell, J. T., Mcleod, E. M., \& G. J. Coleman (2019). When zoo visitors "connect" with a zoo animal, what does that mean? Zoo Biology, 38(6), 461-470.

Kalábová, M. (2019). Economic impact of inbound hunting tourism in the Czech Republic. Studia Turistica, 10(2), 41-47.

Kušen, E. (2010). A system of tourism attractions. Tourism - An international Interdisciplinary Journal, 58(4), 409-424.

Mason, P. (1999). Zoo as heritage tourism attractions: A neglected area of research? International Journal of Heritage Studies, 5(3-4), 193-202.

Mason, P. (2000). Zoo Tourism: The Need for More Research. Journal of Sustainable Tourism, $8(4), 333-339$.

Mooney, A., Conde, D. A., Healy, K., \& Buckley, Y. M. (2020). A system wide approach to managing zoo collections for visitor attendance and in situ conservation. Nature Communications, 11, 584.

Morris, D. (1961). An analysis of animal popularity. International Zoo Yearbook, 2, 60-61.

Moss, A., \& Esson, M. (2010). Visitor Interest in Zoo Animals and the Implications for Collection Planning and Zoo Education Programmes. Zoo Biology, 29(6), 715-731.

Nekolný, L., Fialová, D. (2018a): The issues in methodology and data interpretation in studies of tourist attractions' attendance: annual passes. Acta Universitatis Carolinae Geographica, 53(2), 167-179.

Nekolný, L., Fialová, D. (2018b). Zoo Tourism: What Actually Is a Zoo? Czech Journal of Tourism, 7(2), 153-166.

Newsome, D. (2005). Wildlife tourism. Clevedon.

Shackley, M. (1996). Wildlife Tourism. London: Thomson Learning.

Sheridan, A. (2016). Europas Zoo unter der Lupe: Sheridans Handbuch der Zoos in Europa. Münster: Schüling, K. (Verlag).

Skibins, J. C., Dunstan, E. \& K. Pahlow (2017). Exploring the Influence of Charismatic Characteristics on Flagship Outcomes in Zoo Visitors. Human Dimensions of Wildlife. 1-15.

Smith, L. (2013). Visitors or Visits? An Examination of Zoo Visitor Numbers Using the Case Study of Australia. Zoo Biology, 32(1), 37-44. 
Turley, S. K. (2001). Children and the demand for recreational experiences: the case of zoos. Leisure Studies, 20(1), 1-18.

Zoo has significant economic impact. (2004). Toledo Business Journal, 20(5), 55. Retrieved June 07, 2019 from: https://search-proquest-com.zdroje.vse.cz/docview/195159054?accountid $=17203$

UCSZOO (2017). ZOO Stanovy.

UCSZOO (2018) Výroční zpráva (annual report) UCSZOO. Retrieved June 12, 2019 from: http://www.zoo.cz/media/files/zoo_vyrocni_zprava_2017_web.pdf

UCSZOO (2017). Výroční zpráva (annual report) UCSZOO. Retrieved June 12, 2019 from: http://www.zoo.cz/media/files/vyrocni-zprava-ucszoo_2016.pdf

Whitworth, A. W., Clifton, J. (2012). An Investigation into the Determining Factors of Zoo Visitor Attendances in UK Zoos. PLoS ONE 7(1). DOI: 10.1371/journal.pone.0029839.

World Association of Zoos and Aquariums. Members. Retrieved June 12, 2019 from: https:// www.dropbox.com/s/bksz7wxa6xdlcdw/WAZA_Member_2019.pdf?dl=0

Zákon č. 162/2003 Sb., o podmínkách provozování zoologických zahrad a o změně některých zákonů (zákon o zoologických zahradách). In: Sbirka zákonů. 2003, částka 61. ISSN 12111244. 